\section{Thatcher hosts symposium}

\section{London}

BRITAIN's prime minister, Mrs Margaret Thatcher, demonstrated her resolve to tackle the greenhouse effect by holding a seminar for senior ministers in her home at 10 Downing Street last week. Eight cabinet ministers and 24 scientists and businessmen attended the seminar, which was intended to educate the politicians about the consequences of a global temperature rise and possible measures to prevent it.

Among those present were the heads of the science research councils; the directors of the Meteorological Office, the British Antarctic Survey and the Forestry Commission; the heads of the Central Electricity Generating Board, Shell UK and the Confederation of British Industry; and senior ministers from the departments of energy, environment, education and science, trade and industry, transport, agriculture, health, and for home and foreign affairs.

This unorthodox forum for the discussion of environmental problems seems to illustrate an unusual scientific awareness at the highest levels in any government. Sir George Porter, the president of the Royal Society, said this was "the first time

in history that a head of state has held a scientific symposium in her own home". It is the right way for science to be disseminated through government, and ought to happen more often, he said.

The one-day private discussions began with speakers outlining the problem. Professor Tom Wigley, of the climate research unit at the University of East Anglia, reported climate change predictions. He estimated a global temperature rise of between 1.1 and $1.9^{\circ} \mathrm{C}$ by 2030 , accompanied by a global sea-level rise of $17-26$ centimetres.

The government's adviser from the Energy Technology Support Unit, Ken Currie, described measures which could be taken to mitigate the greenhouse effect. Energy efficiency could make the greatest contribution to reducing emissions of greenhouse gases. Switching from coal-fired to gas-fired generation of electricity, increased use of nuclear power and renewable energy technology would also have a significant effect.

Thatcher now plans to take action to tackle the greenhouse effect at a national level and to urge international action, although no details have yet been announced.

Christine McGourty

\title{
Protests move an airport
}

\section{Tokyo}

INTERNATIONAL criticism has forced Japan to revise its plans to build an airport on top of a coral reef off Ishigaki, an island at the southern end of the Okinawan chain (see Nature 324, 100; 1986). The reef supports extensive stands of a rare species of coral protected by international agreement.

Last week the Environment Agency released a report opposed to the airport plan and within hours the Okinawan Prefectural government, which for years has vehemently resisted opposition to the airport, announced that it was abandoning the site at Shiraho on the east coast of Ishigaki. The Okinawan government then put forward a new proposal to relocate the airport on the reef a few kilometres to the north where the coral is already dead. But conservationists fear that

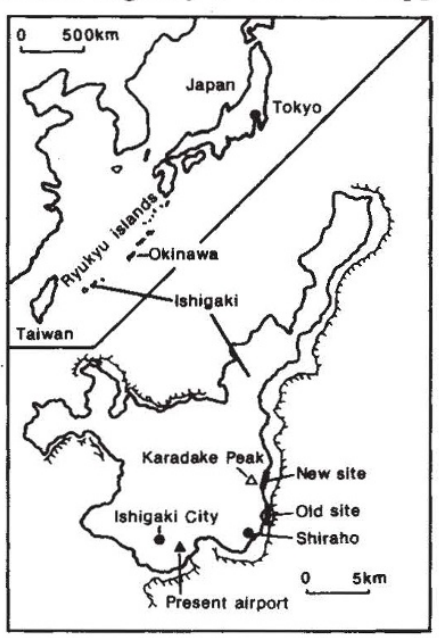

- and opposition to the airport seems likely to continue.

The new airport was first proposed more than a decade ago to allow jumbo jetloads of tourists to fly into the island direct from Tokyo (Ishigaki's present airport is too small to handle jumbo jets and local farmers oppose extension of the runway). But, although the majority of islanders support the airport plan, it has attracted opposition from conservationists around the world because the reef fringing Ishigaki supports extensive stands of the rare Pacific blue coral Helipora cerulea, a species listed under the Convention of International Trade in Endangered Species.

In February last year the International Union for Conservation of Nature and Natural Resources adopted a resolution calling on the Japanese government to abandon the plan. Opconstruction at the new site will still pose a threat to the island's living coral - silt from building activities being one danger has been lacking but the Environment Agency, in an unusual move, carried out

\section{Brazilian general stung by Sting}

\section{São Paulo}

THE growing debate in Brazil about the devastation of the rain forests had its moments of burlesque last week. While the British rock music star Sting toured Europe accompanied by the Brazilian Indian chieftain Raoni in a campaign to save the rain forest, the Brazilian Army minister fumed. "They are actors playing their roles, with financial advantages for both", said General Leonidas Pires Goncalves of the two. But the general then went even further in his comments following a visit to Congress, saying that "the culture of the Indians is very low and doesn't merit respect".

In Congress, homage was being paid to representatives of Indian nations: 19 April is officially 'Indian's day' in Brazil.

Brazilian anthropologists responded angrily to the general's comments. They feared that the statements could incite new violence against the country's natives. Darci Ribeiro, anthropologist and ex-vicegovernor of Rio de Jancito State, said that "Marshal Rondon would be ashamed of his army if he listened to the minister's statements". Marshal Candido Mariano da Silva Rondon (1865-1958) was known for his pioneering work in isolated regions of Amazonia and was a protector of Indians. The state of Rondonia was named after him. Ironically, Rondonia is the most heavily deforested region in Amazonia.

Ricardo Bonalume Neto

an environmental impact assessment in the area in November. The assessment, released last week, concludes that the airport runway, to be constructed by infilling the lagoon between the reef and the shore, "cannot be guaranteed to not have a detrimental effect" on the stands of blue coral that are only metres away.

The Okinawan government had no choice but to abandon the site because Environment Agency approval is required for reclamation sites in the sea over 50 hectares in area. But the new proposal cleverly avoids this limit by locating the runway halfway on land and halfway into the lagoon.

Professor Yuji Yonemori of Ryukyu University, Okinawa, who is one of the few Japanese academics to have opposed the airport, welcomed the decision to abandon the site at Shiraho but worries that construction at the new site, only 4 kilometres away, may have a "bad effect".

Many of the fringing coral reefs in the Okiniwan islands are already dead. Marine biologists are uncertain of the causes but the most likely culprits are runoff of silt from construction and agricultural projects and invasion of the reefs by the coral-eating starfish Acanthaster planci.

David Swinbanks 